\title{
Characterization of lead and arsenic levels in sediment of the lower basin of the San Pedro River, Mexico and its importance regarding human health
}

\author{
B. E. Melendez, A. H. Rubio, R. Quintana \& C. Pinedo \\ College of Zootechnology and Ecology, \\ Autonomous University of Chihuahua, Mexico
}

\begin{abstract}
This study was conducted in a major agricultural area in the state of Chihuahua, Mexico. Sediment samples were collected from five sites in the San Pedro River basin with the objective of detecting levels of cadmium (Cd), arsenic (As) and lead $(\mathrm{Pb})$. Site 1 was located near the Presa las Virgenes dam (PV), site 2 near the locations of Delicias-Rosales (RD), site 3 near the town of Meoqui (M), site 4 in the community of El Torreon (ET) and site 5 near the communities of Junta de los Rios Conchos and San Pedro (LJ). The metals analysis was conducted using an Inductively Couplet Plasma Atomic Emission Spectrometer (ICP-OES) Perkin Elemer 2000. The results were compared with NOM-147SEMARNAT/SSA1-2004. Cd levels were not determined in any soil sample. The results indicated that $\mathrm{Pb}$ levels were below the established NOM-147 and that location $\mathrm{M}$ had the highest value with a mean of $9.15 \mathrm{mg} \mathrm{kg}^{-1}$. The highest concentration levels of arsenic were found in the RD locale with $14.56 \mathrm{mg} \mathrm{kg}^{-1}$ during the December sampling. In conclusion, lead and arsenic levels in mud from the San Pedro River basin are below the norm. Still, As levels might be significant to human health, especially for the communities established along the San Pedro River.
\end{abstract}

Keywords: metals, lead, arsenic, Mexico, human health. 


\section{Introduction}

Certain anthropogenic industrial, agricultural and domestic activities have energized some soil parameters to increase above Maximum Permissible Limits (MPL). These limits are specified in both international and national standards. For example, norm NOM-147-SEMARNAT/SSA1-2004 [1] is specific to Mexican standards. Concentration values in any natural resource like water or soil are higher than those established in the norm and will represent a lower quality in that particular environment. Each bioaccumulation process is due to the inability of any environment or particular organism to release a given contaminant. This process is aggravated throughout the chain trophy.

The presence of metals in water may come from two independent processes. It could come from a natural weathering process occurring in soils and rocks [2, $3]$ with the results then transmitted in the air [4, 5] and water [6]. Another factor could be anthropogenic activities [7-10]. Subsequently, those metals in water might be deposited in sediments, mud or soils where they can exist for several years as a contaminant. Thus, some metals could accumulate in biota or in a human body as a result of the chain trophy and become a potential health risk.

It is a well-known fact that some metals are essential to the human body while others are toxic even in small quantities. The toxicity will depend on the metal, its quantity and the toxic prospective. For instance, metals $\mathrm{Pb}, \mathrm{Cd}$ and $\mathrm{As}$ are considered highly toxic even in a minimal amounts. Detecting metal in water is the first step in explaining some of the pathology and becoming aware of the level of metals in sediments or soils. Gutierrez et al. [11] conducted research concerning the level of metals in water of the San Pedro River located in Chihuahua, Mexico. Although to our knowledge there is no information about the level of metals in sediments of this river. The objective was then to quantify the amount of $\mathrm{Pb}$ and $\mathrm{As}$ in sediments from the San Pedro River. These results will be essential in learning the pollution level in this environment and to discuss health risks to humans, established in communities throughout this river.

\section{Materials and methods}

The study was carried out in the San Pedro River, a tributary of the Conchos River located in the State of Chihuahua, Mexico. The Conchos River joins the Rio Bravo/Rio Grande, which is the natural boundary between Mexico and the United States. The study area is located within Irrigation District 005 which is considered the most important in the state because it irrigates about 84,528 ha [12]. The stretch of the San Pedro River studied here began near Presa las Virgenes (348 million $\mathrm{m}^{3}$ capacity) and continued on to the confluence of the San Pedro River with the Conchos River, before the water was stored again in the Luis L. Leon dam (356 million $\mathrm{m}^{3}$ capacity).

Five site locations throughout the San Pedro River were selected for collection of sediment samples (Figure 1). The samples were obtained in October and December 2005 and April 2006. Site 1 was located near the Presa las Virgenes dam (North Latitude 28 09' 898'; West Longitude $105^{\circ} 37^{\prime} 541^{\prime}$ ) at 
1,206 meters above sea level (masl) and will be referred to as Presa las Virgenes (PV). Site 2 was located between the community of Rosales and the city of Delicias (North Latitude 28 $8^{\circ} 5^{\prime}$ 406'; West Longitude $105^{\circ} 29^{\prime} 4^{\prime} 9^{\prime}$ ) at 1,150 masl and will be referred to as Rosales-Delicias (RD). Sampling site 3 was near the city of Meoqui (North Latitude 28 $16^{\prime} 343^{\prime}$; West Longitude $105^{\circ} 27^{\prime}$ $\left.699^{\prime}\right)$ at 1,132 masl and will be referred to as Meoqui (M). Site 4 was located in the vicinity of the El Torreon community (North Latitude 28 $8^{\circ} 1^{\prime} 335^{\prime}$; West Longitude $105^{\circ} 25^{\prime} 140^{\prime}$ ) at 1,129 masl and will be referred to as El Torreon (ET). Site 5 was in the proximity of the Junta de los Rios community (North Latitude $28^{\circ} 20^{\prime} 998^{\prime}$; West Longitude $105^{\circ} 24^{\prime} 882^{\prime}$ ) at 1,117 masl and will be referred to as La Junta (LJ).

A total of 35 sediment samples were obtained as follows; in October 2005, one sample was obtained from every site (five samples) and then during December 2005 and April 2006 three samples were again taken from every site (30 samples). The samples consisted of 1-2 kg that were drawn with a plastic shovel, collected in plastic bags and transported to the lab at the Faculty of Zootechnology and Ecology of the Autonomous University of Chihuahua for further analysis. Samples were dried, ground and passed through a $0.355 \mathrm{~mm}$ sieve to purge rocks, roots and larger particles. The digestion of the samples was accomplished following method 3050A EPA and the results were compared with the values established in Mexican Norm NOM-147-SEMARNAT/SSA12004 [1]. The metal concentration of $\mathrm{Pb}$, As and $\mathrm{Cd}$ were determined using a Coupled Inductively Plasma-Optical Emission Spectrometry (ICP-OES) Perkin Elmer 2100.

\section{Results and discussion}

Table 1 shows the As levels detected in mud of the San Pedro River. It is obvious that the values are below the limits established by the Mexican Norm [1] that points out a MPL of $22 \mathrm{mg} \mathrm{kg}^{-1}$ for agricultural, residential and commercial use. The higher As mean concentration was observed in RD with $14.56 \mathrm{mg} \mathrm{kg}^{-1}$ which was detected in December, compared to the LJ location where the concentration was $1.11 \mathrm{mg} \mathrm{kg}^{-1}$. Gutierrez et al. [11] who in a water sample study of the Rio San Pedro, detected the level of metals and metalloids, found high variability for As concentration concerning both sampling location and sampling month. These authors reported that the As concentration in water was higher than the values of the Mexican and International standards for drinking water. These As concentration values in water and mud are important because rural inhabitants along river have direct contact with some metals and metalloids by such activities as bathing and crop irrigation. In addition, these results are important because this element has been associated with different diseases [13, 14] specifically its relationship with the development of leukemia [15], cancer $[16,17]$ and abnormalities in children [18]. Another concern is that inhabitants in the communities along the San Pedro River consume fish or other products collected directly from the river that can be potentially toxic due to the chain 


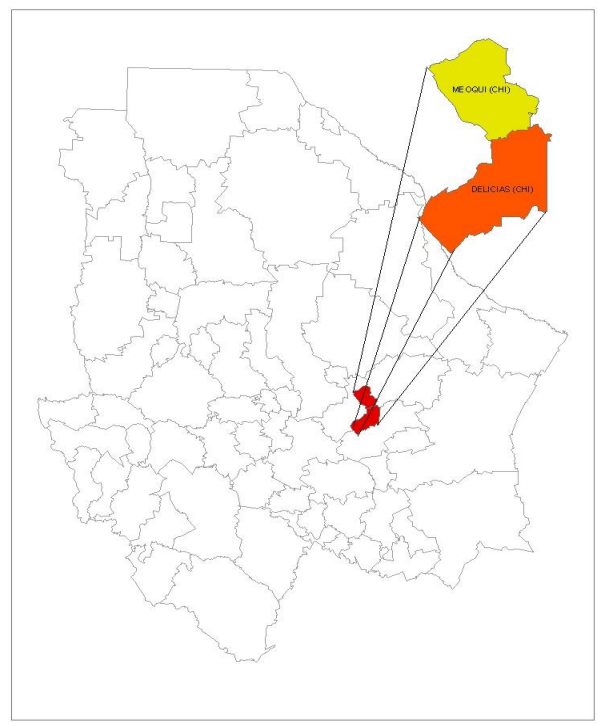

Figure 1: $\quad$ Map of the state of Chihuahua, Mexico, showing the study area.

Table 1: $\quad$ Values of As $\left(\mathrm{mg} \mathrm{kg}^{-1}\right)$ in mud of the San Pedro River in five locations and during three sample months.

\begin{tabular}{|l|c|c|c|c|c|}
\hline Month & \multicolumn{1}{|l|}{$\mathrm{LP}^{\mathrm{a}}$} & \multicolumn{1}{l|}{$\mathrm{RD}^{\mathrm{a}}$} & \multicolumn{1}{l|}{$\mathrm{M}^{\mathrm{b}}$} & $\mathrm{ET}^{\mathrm{b}}$ & $\mathrm{LJ}^{\mathrm{b}}$ \\
\hline October & 5.31 & 11.00 & 6.15 & 4.75 & 5.68 \\
\hline December & 0.56 & 14.56 & 4.91 & 2.83 & 1.11 \\
\hline April & 0.0 & 7.11 & 4.11 & 12.2 & 2.93 \\
\hline
\end{tabular}

$\mathrm{a}$ and $\mathrm{b}$ represent the calculated mean for location where equal letters are similar (Tukey; 0.05 level of significance)

trophy [19]. Furthermore, these products are sold in urban areas near the river, a logical concern to health agencies in Chihuahua.

Table 2 shows the $\mathrm{Pb}$ concentration in mud of the San Pedro River. Obviously, all values are below the limits established in the Mexican Norm [1] that specify a MPL of $400 \mathrm{mg} \mathrm{kg}^{-1}$. The higher $\mathrm{Pb}$ concentration was noted in M during the October sampling with $11.73 \mathrm{mg} \mathrm{kg}^{-1}$. This value is far from MPL values. Even in $\mathrm{LP}$, the $\mathrm{Pb}$ was not detected in the October sample. Here, we must recall that LP is the higher location and this result may be explained by lixiviation due to water irrigation. It is interesting to note that Gutierrez et al. [11] found values of $\mathrm{Pb}$ in the water in the same locations points of $0.019 \mathrm{mg} \mathrm{L}^{-1}$ 
(LP), $0.016 \mathrm{mg} \mathrm{L}^{-1}$ (RD), $0.020 \mathrm{mg} \mathrm{L}^{-1}(\mathrm{M}), 0.022 \mathrm{mg} \mathrm{L}^{-1}$ (ET) and $0.018 \mathrm{mg} \mathrm{L}^{-1}$ (LJ) that are comparatively less than the values noted in this research, meaning that this element precipitates and accumulates over years. The $\mathrm{Pb}$ concentration reported in this study is generally lower than that reported by Rubio et al. [5] in some Mexican soils; likewise, in soils of India with $10.4 \mathrm{mg} \mathrm{kg}^{-1}$ [20] and Japan with $21 \mathrm{mg} \mathrm{kg}^{-1}$ [21].

Table 2: $\quad$ Values of $\mathrm{Pb}\left(\mathrm{mg} \mathrm{kg}^{-1}\right)$ in mud of the San Pedro River in five locations and during three sample months.

\begin{tabular}{|l|c|c|c|c|c|}
\hline \multicolumn{1}{|c|}{ Month } & $\mathrm{LP}^{\mathrm{a}}$ & $\mathrm{RD}^{\mathrm{a}}$ & $\mathrm{M}^{\mathrm{b}}$ & $\mathrm{ET}^{\mathrm{a}}$ & $\mathrm{LJ}^{\mathrm{a}}$ \\
\hline October & 0 & 3.05 & 11.73 & 4.75 & 5.68 \\
\hline December & 5.05 & 3.42 & 8.65 & 5.28 & 5.34 \\
\hline April & 5.78 & 4.11 & 7.09 & 3.83 & 5.24 \\
\hline
\end{tabular}

$\mathrm{a}$ and $\mathrm{b}$ represent the calculated mean where equal letters are similar (Tukey; 0.05 level of significance).

\section{References}

[1] NOM, 2004. NOM-147-SEMARNAT/SSA1-2004, Que establece criterios para determinar las concentraciones de remediación de suelos contaminados por arsénico, bario, berilio, cadmio, cromo hexavalente, mercurio, níquel, plata, plomo, selenio, talio y/o vanadio. Mexico, D.F.

[2] Bozkurtoglu, E., Vardar, M., Suner, F., Zambak, C.A. 2006. New numerical approach to weathering and alteration in rock using a pilot area in the Tuzla geothermal area, Turkey. Engineering Geology 87(1-2):33-47

[3] White, A.F., Marjorie, S.S., Davison, V.V., Alex, E.B., Stonestorm, D.A., Harden, J.W. 2005. Chemical weathering rates of a soil chronosequence on granitic alluvium: III. Hydrochemical evolution and contemporary solute fluxes and rates. Geochimica et Cosmochimica Acta 69(8):1975-1996.

[4] Moreno, T., Querol, X., Castillo, S., Alastuey, A., Cuevas, E., Hermann, L., Mounkaila, M., Elvira, J., Bibbons, W. 2006. Geochemical variation in aeolian mineral particles from the Sahara-Sahel Dust corridor. Chemosphere 65(2):261-270.

[5] Rubio, A.H., Saucedo, T.R., Bautista, M.R., Wood, K., Holguin, C., Jimenez, J. 2006. Are crops and range land being contaminated with cadmium and lead in sediments transported by wind from an adjacent contaminated shallow lake? Geoenvironment and Landscape Evolution. Editors; J.F. Martin-Duqye, C.A. Brebbia, D.E. Emmanouloudis. Witpress, 135-141 
[6] Das, A., Krishnaswami, S. 2007. Elemental geochemistry of river and sediments from the Deccan Traps, India. Implications to sources of elements and their mobility during basalt-water interaction. Chemical Geology 242(1-2):232-254.

[7] Espino, M.A., Rubio, A.H., Navarro, C.J. 2007. Nitrate pollution in the Delicias-Meoqui aquifer of Chihuahua, Mexico. Environmental Health Risk Conference 2007. Republic of Malta, June 27-29, Witpress 189-196.

[8] Rubio, A.H., Wood, K., Alanis, H.E. 2004. Water pollution in the Rio Conchos of northern Mexico. Development and application of computer techniques to Environmental Studies X. Editors; G. Latini, G. Passerini, C.A. Brebbia. Witpress 167-176.

[9] Rubio, A.H., Saucedo, T.R., Lara, C.R., Word, K., Jiménez, J. 2005. Water quality in the Laguna de Bustillos of Chihuahua, Mexico. Water Resources Management III. Editors; M. de Conceicao Cunha y C.A. Brebbia. Witpress 155-160.

[10] Maldonado, V.M., Rubio Arias, H., Quintana, R., Saucedo, T.R., Gutierrez, M., Ortega, J.A., Nevarez, G.V. 2008. Heavy metal content in soils under different wastewater irrigation patterns in Chihuahua, México. International Journal of Environmental Research and Public Health 5(4):289-297.

[11] Gutierrez, L.R., Rubio-Arias, H., Quintana, R., Ortega, J.A., Gutierrez, M. 2008. Heavy metals in water of the San Pedro River in Chihuahua, Mexico and its potential health risk. International Journal of Environmental Research and Public Health 5(2): 91-98

[12] INEGI, 1999. Instituto Nacional de Estadistica Geografia e Informática. Censo del estado de Chihuahua.

[13] Hopenhayn-Rich, C., Biggs, C., Smith, M.C. 1998. Lungs and kidney cancer mortality associated with arsenic in drinking water in Cordoba, Argentina. Int. J. Epidemiol. 27:561-569

[14] NRC, 2001. National Research Council. Arsenic in drinking water, 2001. Update, Washington, D.C. National Academy Press, 2001.

[15] Robinson, L., Links, T., Smith, A., Smith, M., Guinan, M., Todd, R., Brown, L., Dudding, B. 2001. Acute lymphoblastic (lymphocytic) leukaemia-Review and recommendations of the expert panel. Nevada State Health Division

[16] Chen, C.J., Kuo, T.L., Wu, M.M. 1988. Arsenic and cancer. Lancet I: 414415

[17] IARC, 2004. International Agency for Research on Cancer. Some drinking water disinfectants and contaminants including arsenic. IARC Monograr. Eval. Carcinog. Risks Hum. 84

[18] Steinmaus, C., Lu, M., Todd, R.L., Smith, A.H. 2004. Probability estimates for the unique childhood leukemia cluster in Fallon, Nevada and risk near other U.S. Military Aviation facilities. Environmental Health perspectives 112(6):766-771.

[19] Scoot, W., F. G. Prieto., J. C. O. Gaytan., A. E. Zuñiga., 2006. Acumulación, Toxicidad y Teratogénesis Provocada por Presencia de 
Arsénico en Aguas en el Pez Cebra (Danio reio).Disponible en: http://invenia.es/oai:dialnet.unirioja.es:ART0000079109. Accesed febrero 2008.

[20] Roychowdhury, T., Uchino, T., Tokunaka, H., Abd Ando, M. 2002. Arsenic and other heavy metals in soils from an arsenic-affected area of West Bengal, India, Chemosphere 49(6):605-618.

[21] Akira, T., Hirofumi, T., Masami, N., Yuichi, T., Toyokazu, U., Shunñichi, H., Jiro, I. 2005. Effect of long-term fertilizer application on the concentration and solubility of major and trace elements in a cultivated andisol. Soil Sci. Plant., Nutr. 51(2): 251-260. 